\title{
Influence of Cultivars, Plant Spacings, and Mineral NPK Fertilizers Application on Vegetative Growth, Yield and Its Components and Kernels Quality of Sweet Corn (Zea mays var. rugusa, L.)
}

\author{
Zohair Mahmoud Mirdad ${ }^{1}$
}

\begin{abstract}
The aim of this investigation was to study the effects of two different cultivars of sweet corn (Zea mays var. rugusa, L.), three different plant spacings and three different mineral NPK fertilizers levels, and their interactions on vegetative growth, yield and yield components, and kernels quality characters. To achieve this aim, two field experiments were conducted at the Agricultural Research Experiment Station, King Abdulaziz University, HadaAlsham,Saudi Arabia, during 2006 and 2007 summer seasons. The obtained results indicated generally that the differences among the means values of each studied factor, first-and second - order interactions for the vegetative growth, yield and its components, and kernels quality characters, were significant; but, with different magnitudes, during the two summer seasons. Also, the results indicated generally that the cultivar "Merit" was the best for the most studied vegetative growth, and yield and its components characters, whereas, the cultivar "Challenger" was the favourable cultivar for the kernel quality parameters. The results indicated that increasing either plant spacings or the mineral NPK fertilizers was associated with corresponding increments in most of the studied characters of sweet corn, during both summer seasons. Generally, the results of the first-and the secondorder interactions effects on all the studied characters, showed that one of the used cultivars with either widest spacing between plants or/ and the highest level of mineral NPK fertilizers gave the highest means values of all the studied characters, during both growing seasons.
\end{abstract}

\section{INTRODUCTION}

Sweet corn (Zea mays var. rugusa, L.) belong to the family Poaceae. It is annual, herbaceous, and one of the warm season vegetable cops. It is a varity of maize, but, it differs from all other types of corn because it produces and retains a high amounst of sugar contents in the kernels. Since, the kernels of sweet corn accumulate two the three times more sugars in the endosperm than the normal starchy maize (Doehlert et al., 1993), because it has a single gene (a sugary gene) that makes the kernels sweetness, and convert the sugar to starch slowly, preserving the sweetness for longer periods after harvest (Garwood et al., 1976). So, sweet corn grown for edible immature kernels (at milky stage) to be used in many food dishes, cooking ingredient in salads and soups because of its unique taste and high

\footnotetext{
${ }^{1}$ Faculty of Meteorology, Environment and Arid Land Agriculture,

King Abdulaziz University, Jeddah, Saudi Arabia

Received March 8, 2010, Accepted March 27, 2010
}

nutritional values as well as livestock feed, and as row material in industry. Accordingly, sweet corn is a popular vegetable occupying position in many countries of the world, especially, north and west Europe, United States of America as well as Asia; whereas, in Saudi Arabia, the production of sweet corn (as untraditional vegetable crop) is still very limited, mainly due to lack of the information about suitable cultivars, cultivation practices such as fertilization under the prevailing environmental conditions, poor market practices and limited awareness on its use. Nevertheless, farmers may get good income by exporting it to many other countries all over the world.

It is well known that good cultivars are essential for the production of a satisfactory crop of vegetables for both growers and consumers. Factors influencing the productivity of sweet corn and / or maize are numerous and include environmental conditions, cultivars characteristics, soil management practices, fertilizer application, and plant population density (Bhargava and Saha, 1980; Chambi and Taylor, 1986; and Tetio-Kagho and Gardner, 1988) Therefore, improving production of sweet corn could be achieved through improving the cultural practices such as using good cultivars, balanced fertilizers and suitable plant population density. Since, improved cultural practices; such as fertilization, higher yielding cultivars and higher plant populations have led to increase sweet corn production (Patel et al., 1988).

Pertaining the influences of the different cultivars, at the different plant population densities on yield and quality of sweet corn and maize were studied by several investigators, such as (Yodpetch and Bautista (1984); Bauer and Carter (1986), Rogers and Lomman (1988); Falivene (1995), Jagtap et al. (1997); Sukanya et al. (1998), and Akman (2002). They found that ears yield character increased with increasing plant population densities; but, grain yield decreased. Whereas, Navarro et al. (1995); Modarres et al. (1999); Miftahulla et al. (2002) and Amin (2006); who found that grain yield of sweet corn was also increased. However, the used cultivars differed from one to another in their responses to plant population densities. Moreover, Lang et al. (1956) and Keating et al. $(1988 ; 1990)$ reported that the 
optimal density for maximum yield of maize increased as nitrogen supply improved.

Numerous researchers studied the effects of plant population density and cultivars on one or more of the vegetative growth, yield and its components characteristics of sweet corn and maize. Park et al. (1989) found that increasing plant density increased plant height and then declined. Similar finding was, also, obtained by Miftahulla et al. (2002). Studies made by some investigators on the effects of plant density on some characters of sweet corn such as Yodpetch and Bautista (1984) for plant height, ear number and ear length; Rogers and Lomman (1988) for ear diameter and weight of cobs; and Amine (2006) for plant growth. Since, they found that increasing the plant densities have led to decrease in their previously mentioned characters. On the other hand, Mullins (2000) found that plant height, plant diameter, ear weight, ear length, ear diameter and grain yield were not significantly affected by using some sweet corn cultivars and different plant spacings. Also, Hemphill et al. (1996) reported that the effect of row spacings on yield of sweet corn tended to be slightly greater at wider spacing; but, the effect of spacings on ear weight and ear length was not significant. In addition, Akman (2002) determined that lower density gave highest ear length and ear diameter, and these studied characters varied depending on the used cultivars of sweet corn.

Concerning, the effects of mineral fertilizers; i.e., nitrogen, phosphorus and potassium; individually or in combination, with either one or more of each on the sweet corn and/ or maize were reported by several investigators such as Yodpech and Bautista (1984) for ear yield; Peck and MacDonald (1989) for fresh weight of ear; Wong et al. (1995) for ear weight and kernels yield; Hemplill et al. (1996) for ear weight, ear length dry weight, and yield; Michalojc et al. (1996-a) and Nihayati and Damhury (1996) for yield; Miftahulla et al. (2002) for plant height and grain yield and Amin (2006) for plant growth and grain yield. They illustrated generally that increasing in the used mineral fertilizers in their studied characters resulted in increasing effects on all the previously mentioned characters of either sweet corn or maize plants. Also, similar findings were obtained by several investigators such as; Koteva and Mikhov (1995) using NPK on dry matter; Tosheva (1995) using NPK on yield and plant height.

The main objectives of this investigation were to study the effects of different cultivars, plant spacings, different rates of the mineral NPK fertilizers; and their interactions on some growth, yield and its components, and kernels quality components of sweet corn.
During the two successive summer seasons of 2006 and 2007, two field experiments were conducted at the Agricultural Research Experiment Station, King Abdulaziz University, Hada-Alsham. Faculty of Meteorology, Environment and Arid Land Agriculture, Saudi Arabia.

Each experiment contained eighteen treatments, which represented all possible combinations of two sweet corn cultivars (Merit and Challenger), three levels of compound mineral NPK fertilizer at the rates of 100$50-75 ; 200-100-150$, and 300-150-225 kg N-P $\mathrm{O}_{5}-\mathrm{K}_{2} \mathrm{O}$ $\mathrm{ha}^{-1}$. and three different plant spacings 15,25 and $35 \mathrm{~cm}$ between plants.

The forms of the three types of mineral fertilizers, NPK; were used as follows; ammonium nitrate $(33.5 \%$ $\mathrm{N})$, calcium superphosphate $\left(\begin{array}{lll}15.5 \% & \mathrm{P}_{2} \mathrm{O}_{5}\end{array}\right)$ and potassium sulphate $\left(48 \% \mathrm{~K}_{2} \mathrm{O}\right)$. The used experimental layout was a split-split-plot in a randomized complete blocks design (R.C.B.D) with three replications. The used cultivars occupied the main plots; whereas, the mineral NPK fertilizer rates were, randomly, assigned in the sub-plots, and spacings between plants were considered as the sub-sub-plot. Each sub-sub plot consisted of three rows $4 \mathrm{~m}$ long and $0.6 \mathrm{~m}$ wide. A guard row was left without planting to separate each two adjacent sub-sub plot. The same experimental steps were conducted in the first season of 2006, and in the second season of 2007.

Seeds of the two cultivars of sweet corn were, directly, sown on one side of the row at the used plant spacings (20, 25 and 30cm apart) on May 2, 2006 and May 3, 2007. The mineral N, K fertilizers were added to the growing plants in three equal parts at 25, 35 and 45 days from planting. Whereas, calcium super phosphate was broadcasted throughout the soil preparation (before planting). During the growing seasons, all other recommended agricultural practices for the production of sweet corn were followed.

Prior to the initiation of each experiment, soil and water samples were collected and analyzed according to the published methods of Al-Solaimani et al. (2009). Results of the analysis for soil and water are given in Table (1, 2, 3)as average of the two seasons of 2006 and 2007.

Soil $\mathrm{pH}$ and electrical conductivity (EC) were determined by mixing soil with water by $1: 1$ weightvolume $(\mathrm{W}: \mathrm{V})$ ratio using glass rod. The total organic matter (O.M.) in the soil was determined using Walkeley and Black's method as described by Jackson (1973).

\section{MATERIALS AND METHODS}


Table 1. Average soil texture and physical properties of soil analysis of the two seasons of 2006 and 2007

\begin{tabular}{ccccc}
\hline Depth $(\mathbf{c m})$ & Loam $(\boldsymbol{\%})$ & Silt $(\%)$ & Sand $(\%)$ & Soil texture \\
\hline $0-15$ & 9.1 & 4.59 & 80.9 & S.L \\
\hline $15-30$ & 2.59 & 2.84 & 94.5 & S \\
\hline
\end{tabular}

Table 2. Average chemical analysis for soil samples from field experiment of the two seasons of 2006 and 2007

\begin{tabular}{ccccccccccccc}
\hline $\begin{array}{c}\text { Depth } \\
(\mathbf{c m})\end{array}$ & $\begin{array}{c}\mathbf{O} . \mathbf{M} \\
(\boldsymbol{\%})\end{array}$ & $\mathbf{p H}$ & $\begin{array}{c}\mathbf{E C} \\
\mathbf{d S m}^{-1}\end{array}$ & $\begin{array}{c}\mathbf{N} \\
\mathbf{M g} / \mathbf{l}\end{array}$ & $\begin{array}{c}\mathbf{P} \\
\mathbf{M g} / \mathbf{l}\end{array}$ & $\begin{array}{c}\mathbf{K} \\
\mathbf{M g} / \mathbf{l}\end{array}$ & $\begin{array}{c}\mathbf{C a} \\
\mathbf{M g} / \mathbf{l}\end{array}$ & $\begin{array}{c}\mathbf{N a} \\
\mathbf{M g} / \mathbf{l}\end{array}$ & $\begin{array}{c}\mathbf{M g} \\
\mathbf{M g} / \mathbf{l}\end{array}$ & $\begin{array}{c}\mathbf{C l} \\
\mathbf{M g} / \mathbf{l}\end{array}$ & $\begin{array}{c}\mathbf{S O}_{\mathbf{4}} \\
\mathbf{M g} / \mathbf{l}\end{array}$ & $\begin{array}{c}\mathbf{H S O}_{\mathbf{3}}^{-} \\
\mathbf{M g} / \mathbf{l}\end{array}$ \\
\hline $0-15$ & 0.526 & 7.85 & 0.75 & 0.19 & 0.18 & 0.37 & 0.96 & 0.98 & 1.89 & 1.41 & 0.94 & 2.1 \\
\hline $15-30$ & 0.585 & 7.7 & 0.67 & 0.18 & 0.19 & 0.3 & 1.07 & 0.75 & 0.9 & 0.54 & 0.62 & 1.21 \\
\hline
\end{tabular}

Table 3. Average chemical analysis for irrigation water of the two seasons of 2006 and 2007

\begin{tabular}{cccccccccc}
\hline $\mathbf{p H}$ & $\mathbf{E C ~ d S m}^{-1}$ & $\begin{array}{c}\mathrm{Na}+ \\
\mathbf{M g} / \mathbf{l}\end{array}$ & $\begin{array}{c}\mathrm{Ca}^{++} \\
\mathbf{M g} / \mathbf{l}\end{array}$ & $\begin{array}{c}\mathrm{K}^{+} \\
\mathbf{M g} / \mathbf{l}\end{array}$ & $\begin{array}{c}\mathrm{Mg}^{+} \\
\mathbf{M g} / \mathbf{l}\end{array}$ & $\begin{array}{c}\mathrm{Cl}^{-} \\
\mathbf{M g} / \mathbf{l}\end{array}$ & $\begin{array}{c}\mathrm{HSO}_{3}^{-} \\
\mathbf{M g} / \mathbf{l}\end{array}$ & $\begin{array}{c}\mathrm{CO}_{3}^{-} \\
\mathbf{M g} / \mathbf{l}\end{array}$ & $\mathbf{S A R}$ \\
\hline 7.8 & 2.56 & 6.25 & 5.6 & 1.51 & 0.5 & 65.5 & 13.6 & 10.4 & 3.6 \\
\hline
\end{tabular}

The soil nitrogen was determined according to the method of Bremner (1965). The soil nitrogen content was measured by Kjeletec Auto 1030 analyzer. The total amounts of phosphorous, potassium, calcium, magnesium and sodium were determined after they were extracted by digestion method with perchloric and nitric acids method described by Shelton and Harper (1941). Phosphorous content was determined colormetrically at light wave length 640 nanometer using Turner spectro-photometer model 2000; whereas, potassium calcium, magnesium and sodium concentrations were measured in the extraction using Perkin Elmer 5000 AAS. Methods of analysis for irrigation water were exactly the same as those described for soil analysis.

\section{Data Recorded:}

Through the growing seasons, the following data were recorded as follows:

\section{Vegetative growth characters:}

Ten plants from the central two rows in each experimental unit, at the taseling and silking stages (after 35-40 days from sowing date), were randomly collected to measure the following vegetative growth characters; plant height $(\mathrm{cm})$ number of leaves plant $^{-1}$, stem diameter $(\mathrm{cm})$ and leaves dry matter content $(\%)$.

\section{Yield and yield components characters :}

At the harvesting stage; the milky stage, when the kernels moisture content was 75-80\% (Evensen and Boyer, 1986); all husked ears of sweet corn plants in the middle two rows in each experimental unit were harvested to determine the characters; number of ears plant $^{-1}$, since, the total ears yield ha. ${ }^{-1}$; was estimated by weighting all harvested husked ears in each experimental unit, and then converted into tons ha. $^{-1}$; and total number of harvested ears from each sub-sub plot was divided by the number of the harvested plants to estimate the average number of ears plant ${ }^{-1}$. Ten harvested ears from each sub-sub plot were randomly selected to determine averages of husked ear weight $(\mathrm{g})$, ear length $(\mathrm{cm})$, and ear diameter $(\mathrm{cm})$. Sub samples of five husked ears, were also collected randomly to estimate the average of unhusked ear weight (net weight of ear) after removing the husks and shanks. The kernels were separated by cutting from the cobs of the fine selected ears and weighed. Then, the weight of the kernels were divided by the five ears to estimate the kernels weight ear $^{-1}(\mathrm{~g})$, which were used to estimate the kernels weight plant $^{-1}$, then converted into tons ha. ${ }^{-1}$ to calculate kernels yield ha. ${ }^{-1}$ (tons).

\section{Kernels quality:}

The kernels quality were expressed by the grains constituents of dry matter, sucrose, starch, carbohydrates; (expressed as \%), and total soluble solids (T.S.S.\%). Immediately after harvesting, Kernels of the collected ears samples, as previously mentioned; were bulked for each sub-sub plot and then kernels samples were randomly taken to determine the kernels constituents of sucrose, starch, , total soluble solids, and dry matter content. Total soluble solids percentages readings were taken for samples of immature kernels, after extracting of the kernels juice, by a hand refractometer. Thirty grams samples of kernels were oven dried at $70^{\circ} \mathrm{C}$ for 48 hours to a constant weight and reweighed to estimate the percentage of kernels dry matter. Sub samples of dried kernels were then taken, ground into powder with a coffee grinder for subsequent sucrose, and starch. Determination of sucrose concentration (\%) was conducted as outlined by 
Cornin and Smith (1979). Phenol sulphoric acid method proposed by Malik and Singh (1980) was to determine the starch content in grains.

\section{Statistical analysis:}

Appropriate analysis of variance of the experimental data were performed (using CoStat - Software program of analysis, 2004). Comparisons among the means of different treatments were undertaken, using Duncan's multiple range test procedure at $\mathrm{p}=0.05$ level, as illustrated by Steel and Torrie (1984).

\section{RESULTS AND DISCUSSIONS}

The results of the main effects of sweet corn cultivars, plant spacings and mineral NPK fertilizers, and their first-and second-order interactions on vegetative growth, yield and its components characters and kernels quality of sweet corn plants, in the two growing seasons of 2006 and 2007, are presented in Tables from 4 to 12 .

\section{Vegetative Growth Characters:}

The results of the main effects of the different studied factors; i.e., two cultivars, three plant spacings and three mineral NPK fertilizers, on vegetative growth characters of sweet corn, in the two growing seasons, are presented in Table 4. The results of the comparisons between the two cultivars means of the characters plant height, stem diameter, number of leaves plant ${ }^{-1}$ and leaves dry matter content, in the two growing seasons, illustrated generally that the differences between the means of these two cultivars appeared to be significant. The results showed also that cultivar "Merit", significantly, gave the highest mean values of plant height, stem diameter and number of leaves plant ${ }^{-1}$, during the two summer seasons. Meanwhile, the cultivar "Challenger" gave the highest mean value for the leaves dry matter content character, in the seasons of 2006 and 2007. Such results indicated generally that the used cultivars varied in their performances for these characters. The obtained results concerning plant height and stem diameter characters were in general accordance with those reported by Akman (1998) for plant height and Mullins (2000) for plant height and stem diameter, who found that cultivars of sweet corn reflected significant differences for these characters.

Concerning the main effect of the different plant spacings on the four vegetative growth characters, in Table 4, the results reflected, generally, that the comparisons among the mean values of all the studied vegetative growth characters; i.e., plant height, stem diameter, number of leaves plant ${ }^{-1}$ and leaves dry matter content; appeared to be significant, in both seasons. The results reflected that using narrow spacing between plants $(15 \mathrm{~cm})$ gave the tallest plants of plant height character, in the two seasons. This result seemed to agree with the findings of Akman (2002) and Miftahulla (2002), who found that plant height character of sweet corn, significantly, increased through the increasing of plant population. On the contrary, Yodpetch and Bautista (1984), in their studies on sweet corn, found that the tallest plants were obtained at low density; while the shortest plants were obtained with the highest population density. With respect to the characters stem diameter, number of leaves plant ${ }^{-1}$ and leaves dry matter content, the results illustrated that using the widest spacing between plants gave the significant highest mean values for the three mentioned characters. These results were in line with those obtained by Amin (2006), who stated that increasing plant density significantly reduced plant growth characters of sweet corn.

As for the main effect of mineral NPK fertilizers levels on the vegetative growth characters, the results in Table 4 showed generally that the application of mineral NPK fertilizer to the grown plants, irrespective of the used amount significantly gave longer plants, thicker stems, more number of leaves plant ${ }^{-1}$, and heavier dry matter content, during the two growing seasons. The previously mentioned results could be explained on the basis of the availability of the nutritive elements of the mineral NPK fertilizers in the soil. The obtained results, in the present study, reflected also that application of $300-150-225 \mathrm{~kg} \mathrm{~N}-\mathrm{P}_{2} \mathrm{O}_{5}-\mathrm{K}_{2} \mathrm{O}$ ha $^{-1}$ gave significantly the highest mean values of the four vegetative growth characters, during the years of 2006 and 2007. These results were in line with those obtained by Amin et al. (2006), using NP fertilizers on sweet corn plants vegetative growth characters. Since, they found that addition of mineral fertilizers with high levels to the plants significantly increased such characters. On the contrary, such results disagreed with the findings of Eltelib et al. (2006), who found that number of leaves plant $^{-1}$, plant height and stem diameter characters were not significantly affected by using nitrogen and phosphorus fertilizers.

The results in Table 5 illustrated the effects of the first-order interaction between each of cultivars X plant spacings, cultivars X mineral NPK fertilizers, and plant spacings $X$ mineral NPK fertilizers, on the vegetative growth characters, during the two summer seasons. The results showed generally that the differences among the mean values of each two combination of the studied factors in all the vegetative growth characters were found to be significant, but, with different magnitudes, through the two seasons. On the contrary, Mullins (2000), in his study, on the plant height and stem 


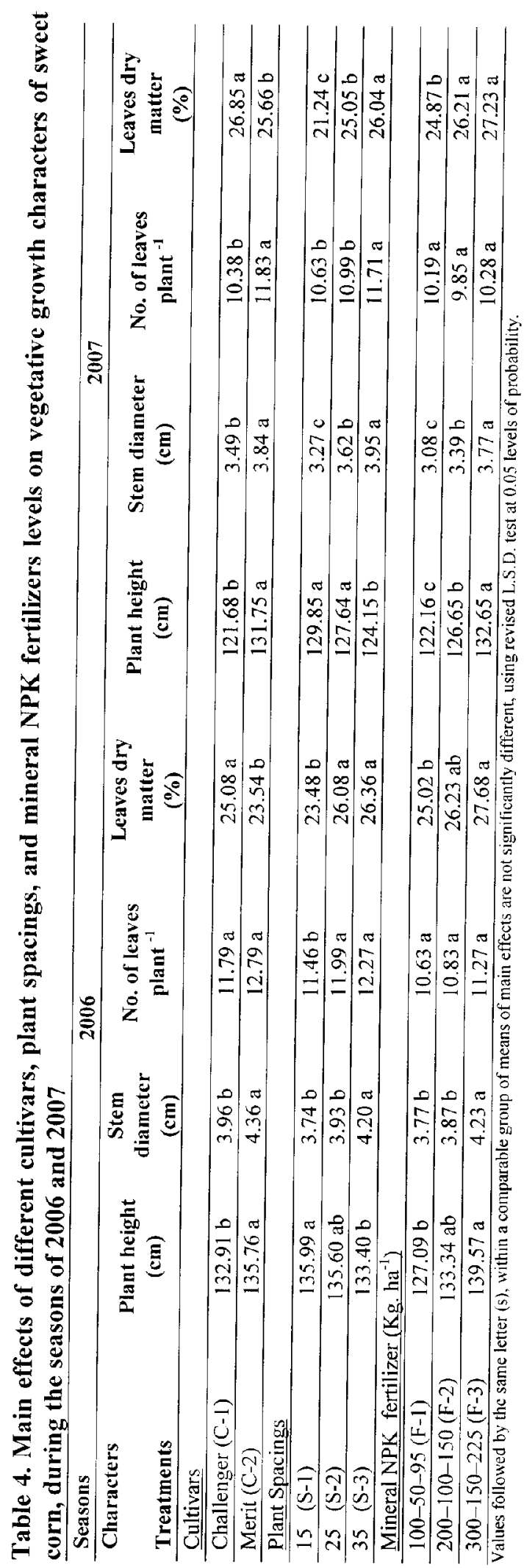




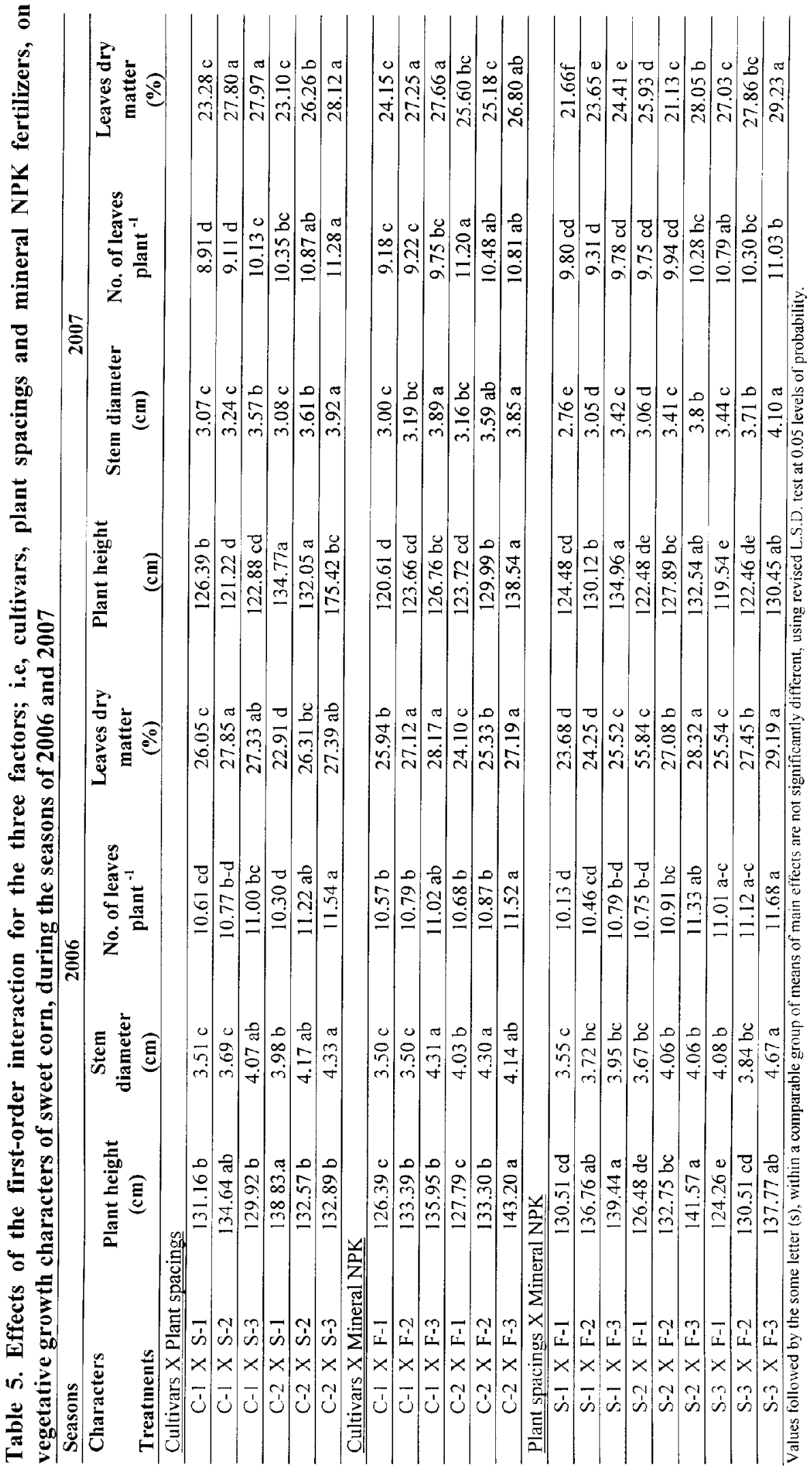


diameter of sweet corn reported that using the interaction between plant densities and cultivars on these two characters reflected insignificant effect. The obtained results reflected also that the treatment combination between cultivar "Merit" and the spacing between plants at 15 (C-2 x S-1) gave the significant highest mean value of plant height, in both seasons. The best treatment combination, which reflected the highest mean value for the characters stem diameter and number of leaves plant ${ }^{-1}$, was between cultivar "Merit" and the widest plant spacing at $35 \mathrm{~cm}(\mathrm{C}-2 \times \mathrm{S}-3)$ in both seasons. The favorable treatment combination that gave the highest mean value of leaves dry matter content, was the combination between cultivar "Challenger" with $25 \mathrm{~cm}$ between plants (C-1x S-2), during the two seasons of 2006 and 2007.

Results in Table 5 showed generally that the effects of treatment combinations among the two cultivars and the different levels of mineral NPK fertilizer on all vegetative growth characters were found to be significant in most cases, during the two growing seasons. This showed generally that the cultivars responded well to fertilization by using mineral NPK fertilizers and gave the most favourable performances for all studied vegetative growth characters of sweet corn.

The interaction between cultivar "Merit" and the addition of mineral NPK fertilizers at the rate of 300150-225 kg N-P $\mathrm{O}_{5}-\mathrm{K}_{2} \mathrm{O}$ ha $^{-1}(\mathrm{C}-2 \times \mathrm{F}-3)$ gave the significant highest mean value of plant height in both seasons. The best treatment combination that gave the highest mean values of stem diameter and leaves dry matter content, in both seasons, was the combination between cultivar "Challenger" with the third rate of mineral fertilization (C-1 $\mathrm{x}$ F-3). Concerning the character number of leaves plant ${ }^{-1}$, the results reflected that the best interactions were the combinations between cultivar "Merit" with the third level of mineral NPK fertilization (C-2 $\times$ F-3), in the first season, and the combination between cultivar "Merit" and the first level of mineral NPK fertilization (C-2 x F-1), in the second season. The favourable effects of mineral NPK fertilizers on vegetative growth characters of sweet corn could be explained on the basis of the fact that these elements played major roles on plant life and stimulated the meristemic activity, which in turn, resulted in more new tissues and organs (Marschner, 1986).

The results of the interaction between plant spacings and mineral NPK fertilizers illustrated that the combination between the first plant spacing $(15 \mathrm{~cm})$ and the third level of NPK fertilizer (300-150-225 kg N$\mathrm{P}_{2} \mathrm{O}_{5}-\mathrm{K}_{2} \mathrm{O}$ ha $^{-1}$ ) gave the highest mean value of plant height, in both growing seasons. The results showed also that the most favourable interaction that gave the highest mean values for the characters stem diameter, number of leaves plant ${ }^{-1}$ and leaves dry matter content, was the combination between plant spacing at $35 \mathrm{~cm}$ between plants and using the mineral NPK fertilizer at the rate of $300-150-225 \mathrm{~kg}$. N- $\mathrm{P}_{2} \mathrm{O}_{5}-\mathrm{K}_{2} \mathrm{O} \mathrm{ha}{ }^{-1}$.

Results in Table 6 reflected the effects of the second-order interaction among the two cultivars, three plant spacings and three levels of mineral NPK fertilizers on all vegetative growth characters, in the two experimental seasons of 2006 and 2007. The results showed generally that the effects of the interactions among the three studied factors on all vegetative growth characters were found to be significant in most cases, in the two summer seasons. The best interaction which gave the highest mean value of plant height was the combinations among cultivar Mrit X plant spacing at 15 $\mathrm{cm} X$ mineral NPK fertilizer at $300-150-225 \mathrm{~kg}$. N$\mathrm{P}_{2} \mathrm{O}_{5}-\mathrm{K}_{2} \mathrm{O}$ ha ${ }^{-1}$. (C-1 X S-1 X F-3). The obtained results illustrated also that the favourable interaction effect of the three studied factors was the combination among the cultivar "Merit" with the third plant spacing at $35 \mathrm{~cm}$ and the third level of mineral NPK fertilizer at the rate of 300-150-225 kg. N-P $\mathrm{O}_{5}-\mathrm{K}_{2} \mathrm{O} \mathrm{ha}^{-1}$., since they gave the highest mean values of the characters stem diameter, number of leaves plant ${ }^{-1}$ and leaves dry matter content, in both seasons. Such results showed generally that the ability of the used hybrids of sweet corn to produce thicker stem, more number of leaves plant ${ }^{-1}$ and heaver dry matter content as affected by using the widest plant spacing and by application of mineral NPK fertilizers, might be related to the genetic potential of these hybrids.

\section{Yield and yield components:}

The results of the main effects of the two cultivars of sweet corn, three plant spacings and three levels of mineral NPK fertilizers on the yield and yield components characters are presented in Tables 7-a and 7-b. The results of the comparisons among the mean values of the studied yield and yield components characters illustrated generally that there were significant differences, with different magnitudes in most cases, in the two growing seasons. The highest mean values for the characters number of ears plant ${ }^{-1}$, husked ear weight, unhusked ear weight, ear length and diameter, kernels weight per ear, plant and hectare was given by the cultivar "Merit", comparing with cultivar "Challenger", during the two growing seasons. The previously mentioned results for yield and yield components characters were in general accordance with those reported by Lana (1956) for ear weight, number 
of ears plant ${ }^{-1}$ and kernels yield; Zhong (1998) for ear weight and grain yield. length and ear diameter; and Mullins (2000) for ear

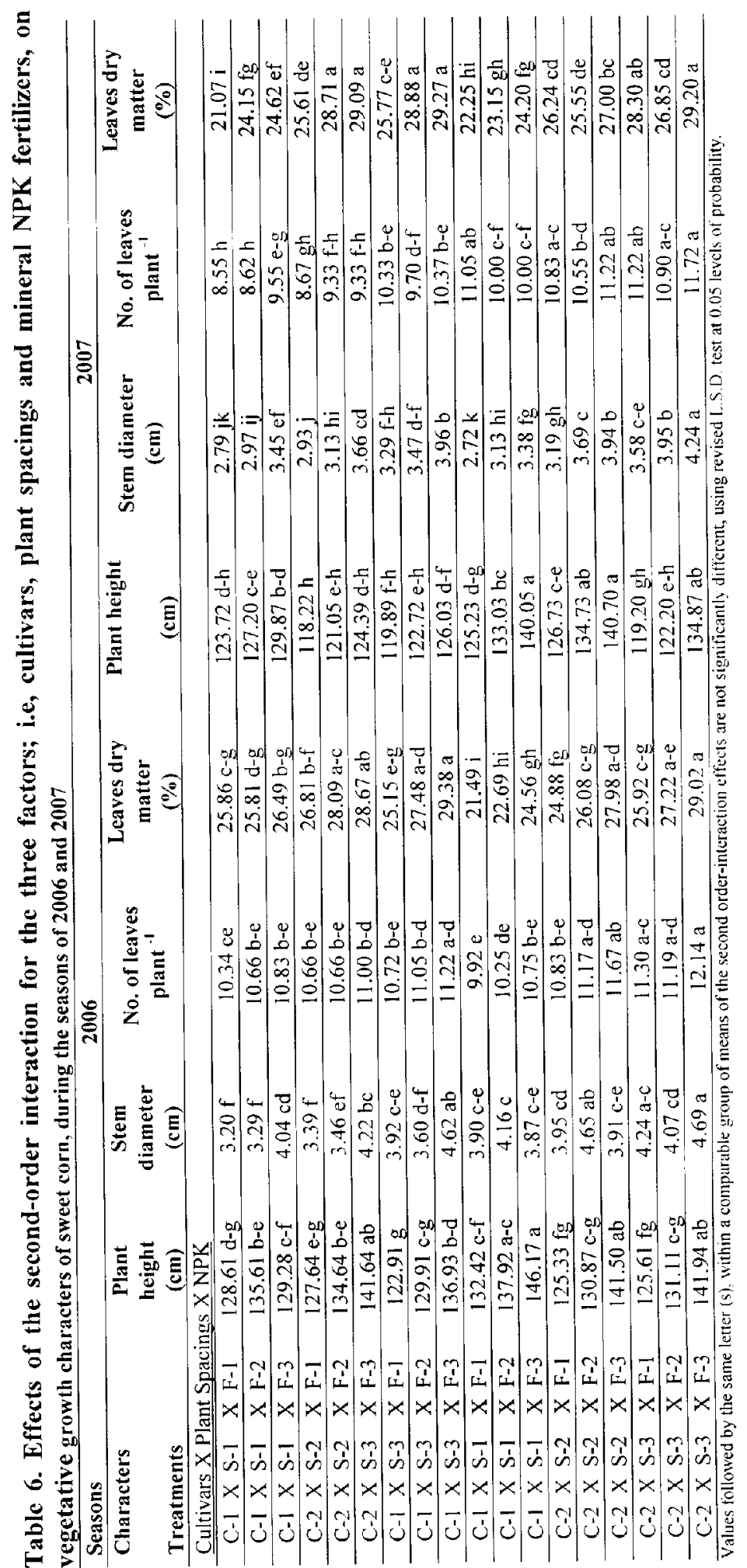




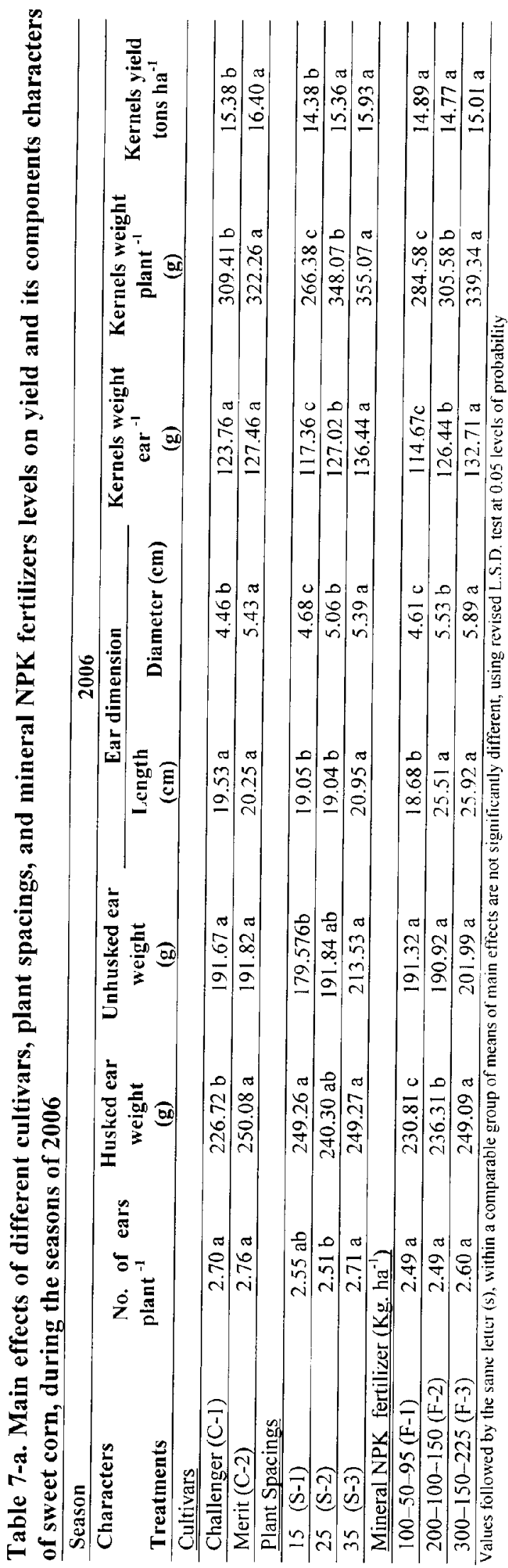




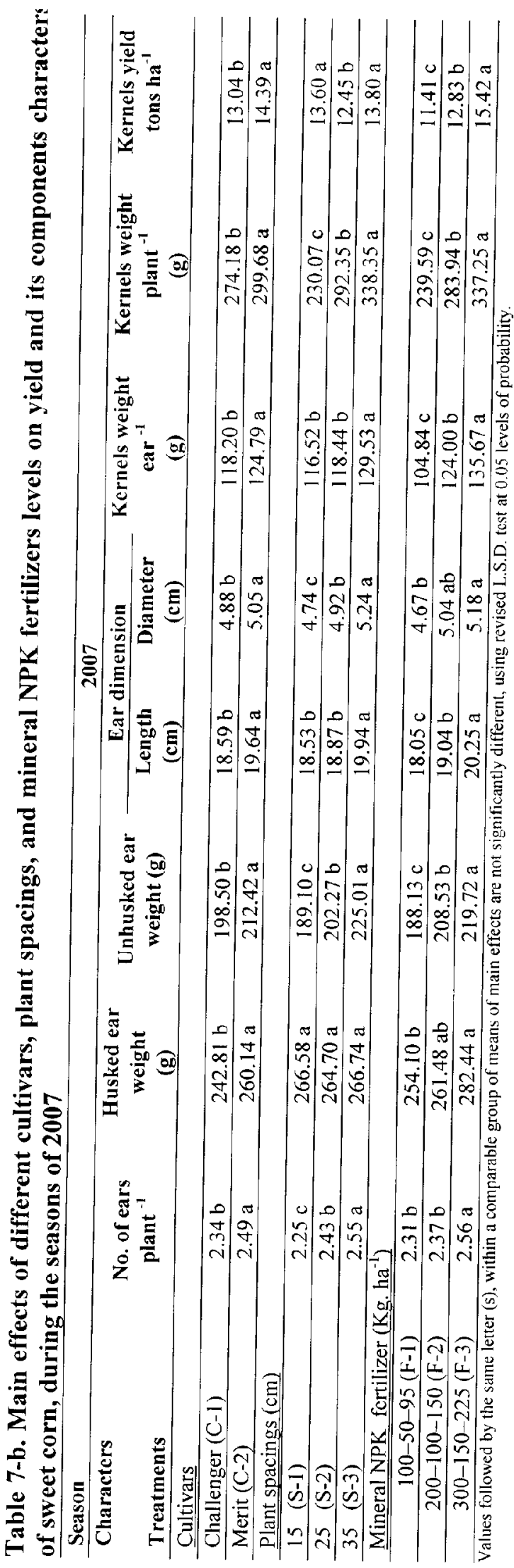


As for the effects of the used plant spacings on the studied yield and its components characters, the results showed generally that increasing the spacings between plants was associated with the corresponding increases in the mean values of these characters, with significant differences in all cases, with few exceptions, during the seasons of 2006 and 2007. These results reflected general accordance with those reported by Sukanya et al. (1998) for grains yield of sweet corn; Akman (2002) for ear length and ear diameter of sweet corn; and Miftahulla et al. (2002) for number of ears plant ${ }^{-1}$ of sweet corn. Since these authors found that increasing the distance between plants resulted in increases in their studied characters. On the contrary, the obtained results disagree with the finding of Amin (2006) for grain yield; and Chipman and Mackay (1960) for ear weight and number of ear plant ${ }^{-1}$.

The results of the effects of mineral NPK fertilizers levels on yield and its components characters illustrated generally that the comparisons among the mean values of all studied characters appeared to be significant, in the two seasons. Since, the increments of the mineral NPK fertilizers levels were associated with corresponding increases in all studied yield and its components characters. Such results were in general agreement with the findings of many researchers such as Yodpetch and Bautista (1984) for ear weight; Wong et al. (1995) for ear weight, ear length, and kernels yield; and Oikeh et al. (1997). These investigators reported that increasing the mineral fertilizers levels reflected significant increases on yield and its components. The obtained results showed also that addition of mineral NPK fertilizers at the rate of 300$150-225 \mathrm{~kg}$. N-P $\mathrm{P}_{2} \mathrm{O}_{5}-\mathrm{K}_{2} \mathrm{O} \mathrm{ha}^{-1}$. gave higher mean values of sweet corn yield and yield components characters, comparing with the other two rates, during both seasons.

The results of the first-order interaction effect on the yield and yield components characters for the two growing seasons, are shown in Tables 8-a and 8-b. Concerning the interaction between the two cultivars of sweet corn and the three plant spacings, the results revealed generally that the comparisons among the mean values of the studied yield characteristics appeared to be significant. However, these obtained results did not cope with those obtained by Mullins (2000) and Akman (2002) for ear length, ear diameter, and ear weight. These authors reported that the interaction effects between cultivars of sweet corn and plant densities were not found significant on their studied characters. The obtained results, in Table 8-a and $8-b$, reflected that the highest significant mean values of the yield and its components characters; i.e. number of ears plant ${ }^{-1}$, husked ear weight, unhusked ear weight, ear length, ear diameter, kernels weight ear $^{-1}$, kernels weight plant $^{-1}$ and kernels yield ha ${ }^{-1}$, was given by the combination between the cultivar "Merit" and the plant spacing at $35 \mathrm{~cm}$, in both seasons. Such results reflected generally that the used cultivars of sweet corn might be reacted well with widest spacings between plants.

Concerning the results of the interaction effects between the cultivars and mineral NPK fertilization on yield and yield components, in Tables 8-a and 8-b, the comparisons among the mean values of the studied two factors for each studied parameter of yield and yield components were found to be significant in most cases, in the two seasons of 2006 and 2007. The results showed that the optimum interactive treatment combination for all the studied characters was between the cultivar "Merit" and the highest level of mineral NPK fertilizer at the rate of $300-150-225 \mathrm{~kg}$. N-P $\mathrm{N}_{2} \mathrm{O}_{5^{-}}$ $\mathrm{K}_{2} \mathrm{O}$ ha $^{-1}$., which gave the highest mean values of the yield and yield components characters, during the two growing seasons. Such results indicated generally that the used two sweet corn cultivars reflected high responses to the fertilization by using mineral NPK fertilizes. These results seemed to agree with the findings of Wong et al. (1995) for ear weight, kernels yield, ear length of sweet corn; and Oikeh et al. (1997) for grain yield and kernels yield of maize.

The results of the first-order interaction effects among the three plant spacings and three levels of mineral NPK fertilizers on the yield and yield components characters revealed generally that the comparisons among the means values of all the studied characters appeared to be significant in most cases, during both seasons. The results illustrated also that the most favorable interaction that was gave the highest mean values of the studied yield and its components characters was the combination between the widest plant spacings $(35 \mathrm{~cm})$ and the highest level of mineral NPK fertilizers at the rate of 300-150-225 kg. N-P $2 \mathrm{O}_{5^{-}}$ $\mathrm{K}_{2} \mathrm{O}$ ha $^{-1}$., through the two growing seasons.

The results of the second-order interaction effects among the three studied factors on the yield and yield components, in the two summer seasons, are presented in Tables 9-a and 9-b. The obtained results reflected generally that the comparisons among the means values of the yield and its components characters appeared to be significant, but with different magnitudes. The results reflected also that the best interaction effects which gave the highest mean values for all the studied characters; i.e., number of ears plant ${ }^{-1}$, husked ear 
weight, unhusked ear weight, ear length, ear diameter, yield ha ${ }^{-1}$. kernels weight ear ${ }^{-1}$, kernels weight plant ${ }^{-1}$ and kernels

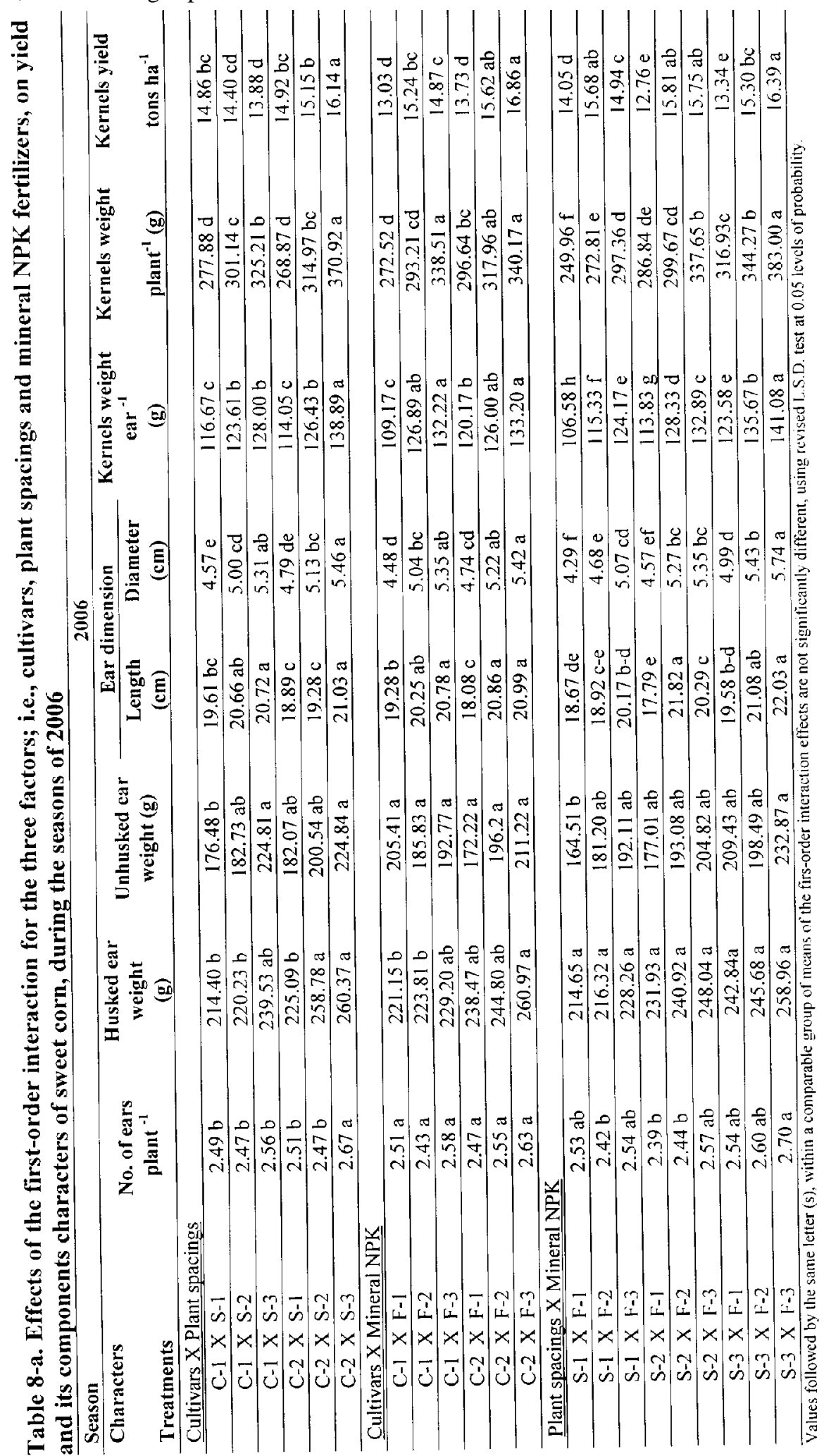




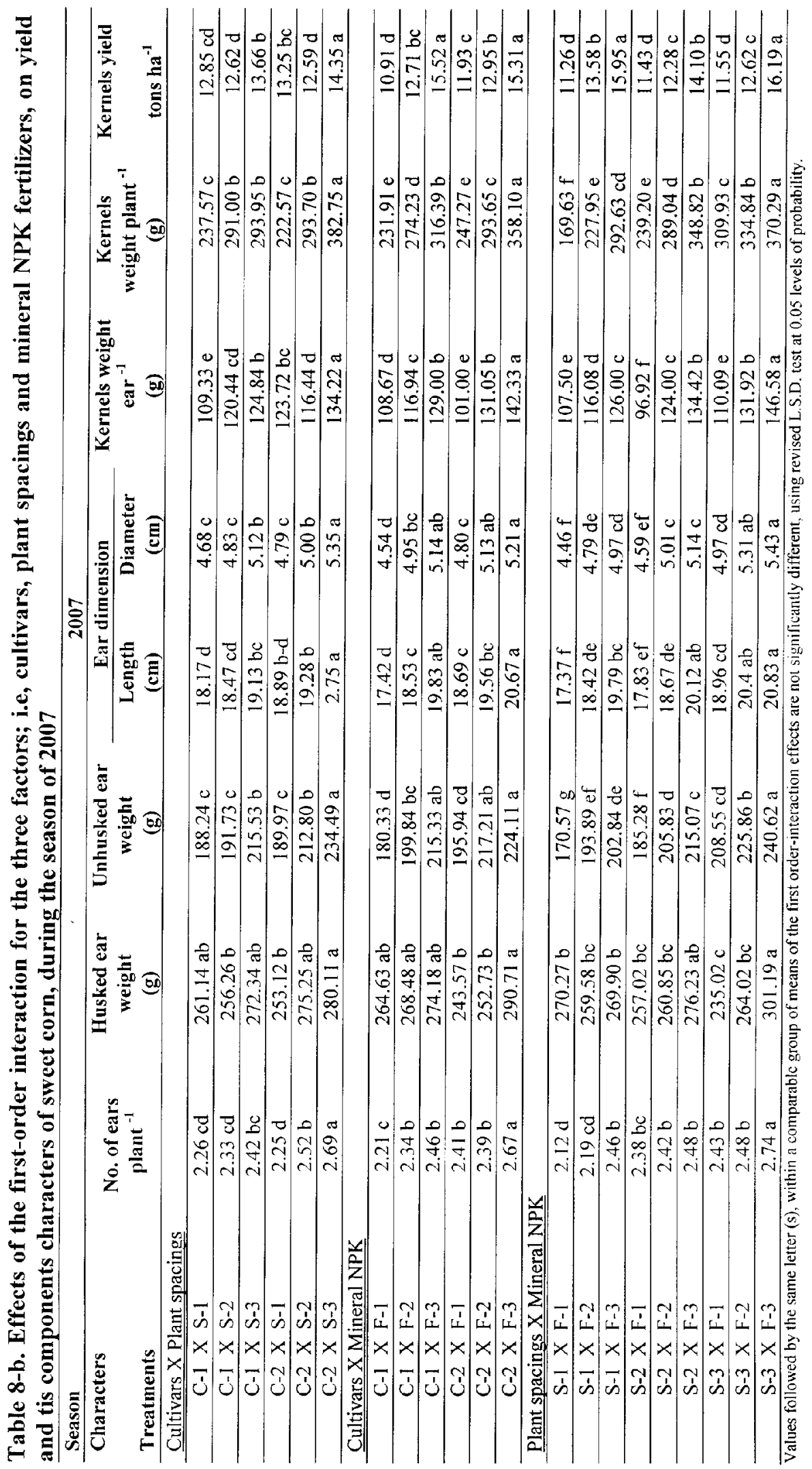




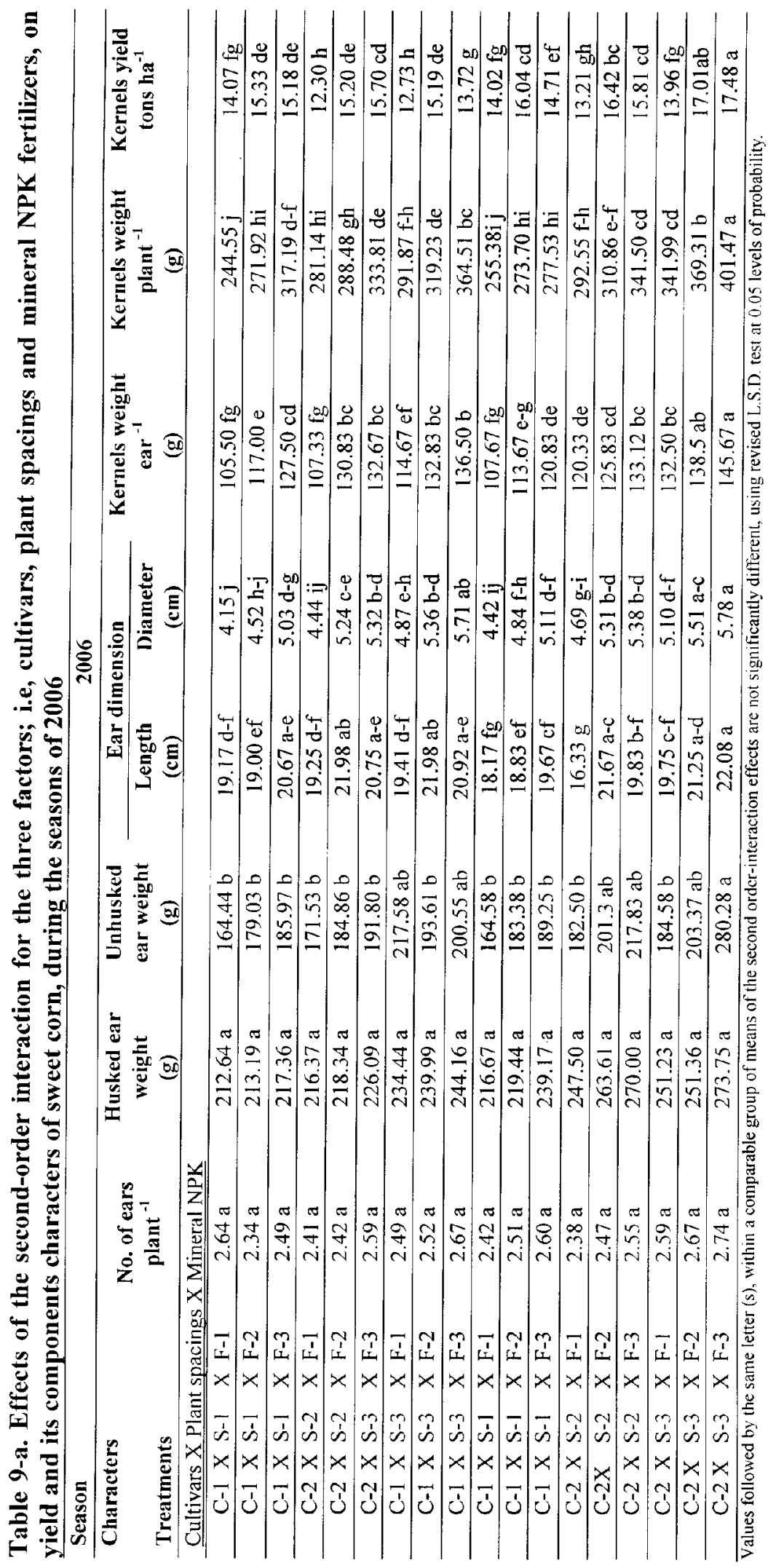




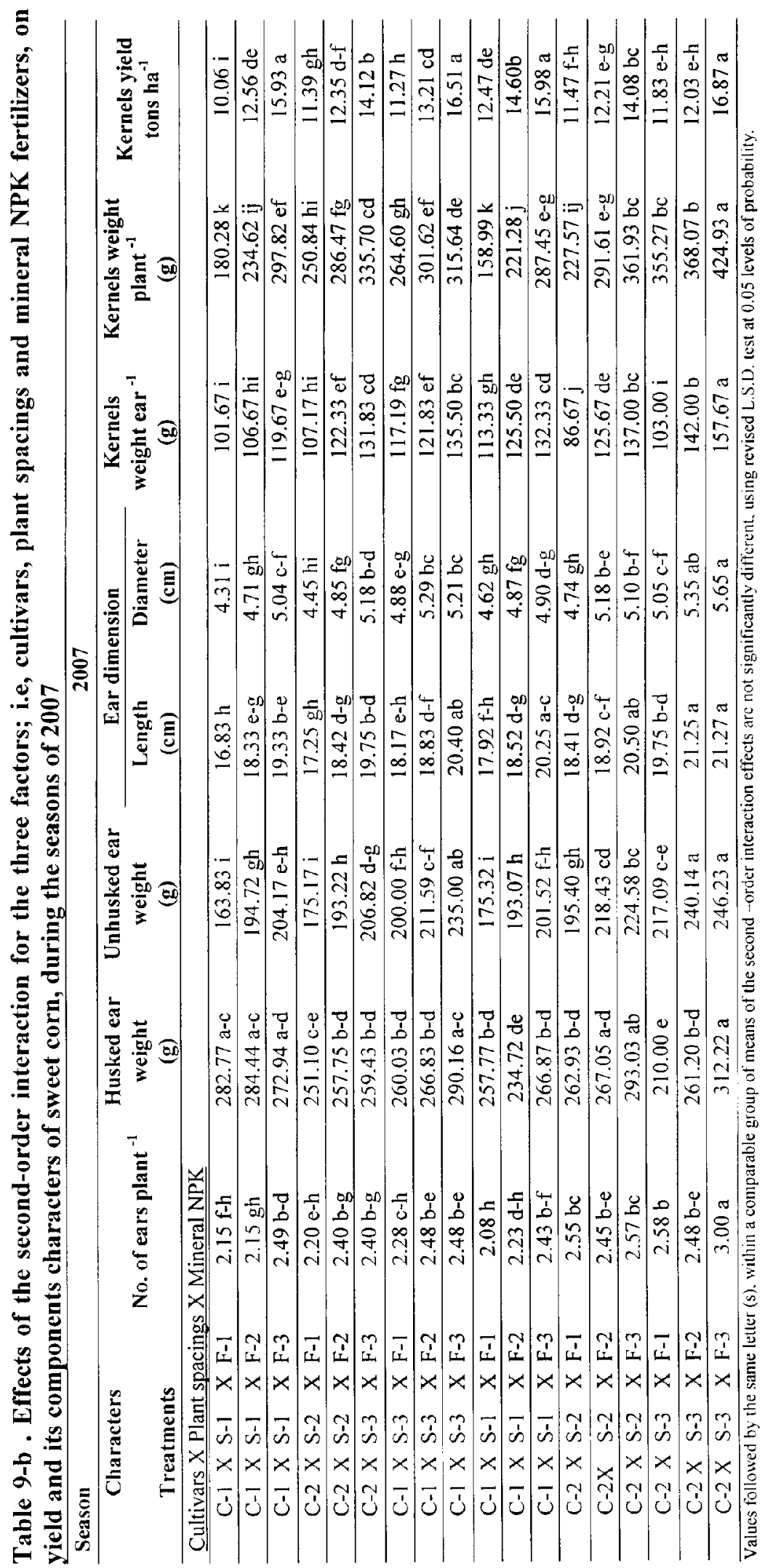


was the combinations among cultivar "Merit" with 35 $\mathrm{cm}$ plant spacings and using the NPK fertilizer at the rate of $300-150-225 \mathrm{~kg}$. $\mathrm{N}-\mathrm{P}_{2} \mathrm{O}_{5}-\mathrm{K}_{2} \mathrm{O}$ ha $^{-1}$., during the two growing seasons. Such results reflected generally that the used hybrids of sweet corn reflected high responses to the wide spacings between plants and application of mineral NPK fertilizers at high level.

\section{Kernels quality parameters:}

The results of the main effects of the used three factors; i.e., two cultivars, three plant spacings and three levels of mineral NPK fertilizers; on the kernels quality parameters as presented by total soluble solids, kernel dry matter content, sucrose and starch; during the two summer seasons of 2006 and 2007, are shown in Table 10. The results illustrated generally that the comparisons among the mean values of each the three studied main factors for all the studied kernels quality parameters reflected significant differences, with few exceptions, in both growing seasons. Regarding the comparisons between the two cultivars mean values of the kernel quality parameters, the results indicated that cultivar "Challenger" was the best cultivar, which gave the highest significant mean values for total soluble solids and sucrose contents, in the two seasons. Meanwhile, cultivar "Merit" gave the highest significant values of kernel dry matter and starch contents in the first and the second seasons. These results were in general agreement with those obtained by Evensen and Boyer (1986) for starch and sucrose; and Kleinhez (2003) for soluble solids; who found that the contents of these compositions were significantly affected by different cultivars of sweet corn. Doehlert et al., (1993) found that lines of sugary genotypes of sweet corn differed in their kernels dry matter contents, and explained this result on the basis that sugary kernels are attributed to a decrease in starch and phytoglycogen in the endosperm.

Concerning the effects of plant spacings treatments on kernels quality parameters, the results indicated generally that cultivated at widest spacings $(35 \mathrm{~cm})$ significantly increased all kernels quality components than cultivation at either 15 or $25 \mathrm{~cm}$, in both years. Since, using spacing between plants at $35 \mathrm{~cm}$ resulted in the highest mean values of total soluble solids, kernels dry matter, sucrose and starch contents, in the two seasons. These results seemed generally to indicate that the used hybrids cultivars of sweet corn reflected higher responses for these constituents at widest spacing.

The results of the effects of the main effect of mineral NPK fertilizer on the kernels quality parameter, in Table 10, illustrated generally that application of NPK in successive amounts up to $300-150-225 \mathrm{~kg}$. N-
$\mathrm{P}_{2} \mathrm{O}_{5}-\mathrm{K}_{2} \mathrm{O} \mathrm{ha}^{-1}$, resulted in steady corresponding increments on the kernels quality parameters; i.e., total soluble solids, kernels dry matter, sucrose and starch contents; in both growing seasons. The highest kernels quality parameters were given by applying mineral NPK fertilizers at the highest rate of $\mathrm{N}-\mathrm{P}_{2} \mathrm{O}_{5}-\mathrm{K}_{2} \mathrm{O}$. Concerning the kernels dry matter content, Michalojc et al. (1996-b) found that $\mathrm{N}$ fertilizer application had a little effect on dry matter content of sweet corn. Concerning the starch content in kernels of sweet corn, in the present study, seemed to disagree with that obtained by Koteva (1995), who found that starch of maize decreased by increasing NPK fertilizer rates. The results of the sucrose content can be explained on the basis that sucrose, which gives sweetness to kernels, is dominant sugar and can be considered the responsible factor for quality of sweet corn (Boyer and Shannon, 1983). It is possible, also, due to the fact that potassium activates the enzymes involved in sugar biosynthesis and helps in translocation of sugars

The results of the first-order interaction effects for the studied factors on kernels quality parameters are shown in Table 11. The results of the interaction effects between the two cultivars of sweet corn and the three plant spacings illustrated generally that using each cultivar with increasing of plant spacings between plants was associated with corresponding increases in the averages of most studied kernels quality parameters, in both growing seasons. These results suggested generally that the used cultivars of sweet corn interacted well at the widest spacings between plants, and gave the most favorable performances for these parameters. The results illustrated also that the best interactive effect, which gave the highest mean values of the two kernels quality parameters total soluble solids and sucrose was given by the combination between the cultivar "Challenger" and the third plant spacing $30 \mathrm{~cm}$ between plants. The combination between cultivar "Merit" and the spacing between plants at $35 \mathrm{~cm}$ gave the highest means values of kernels dry matter and starch contents, in both seasons.

The results of the comparisons among the means values of all the studied kernels quality parameters as affected by the interaction effects between the cultivars and the mineral NPK fertilizers levels, illustrated generally that the two cultivars of sweet corn responded significantly to increments of mineral NPK fertilizers rates, in the two growing seasons. The results showed that the interaction between cultivar "Challenger" and the mineral NPK fertilizer at the rate of 300-150-225 kg. N-P $\mathrm{O}_{5}-\mathrm{K}_{2} \mathrm{O} \mathrm{ha}^{-1}$., gave the significant highest mean values of total soluble solids and sucrose contents, in both seasons. Nevertheless, the highest mean values of 


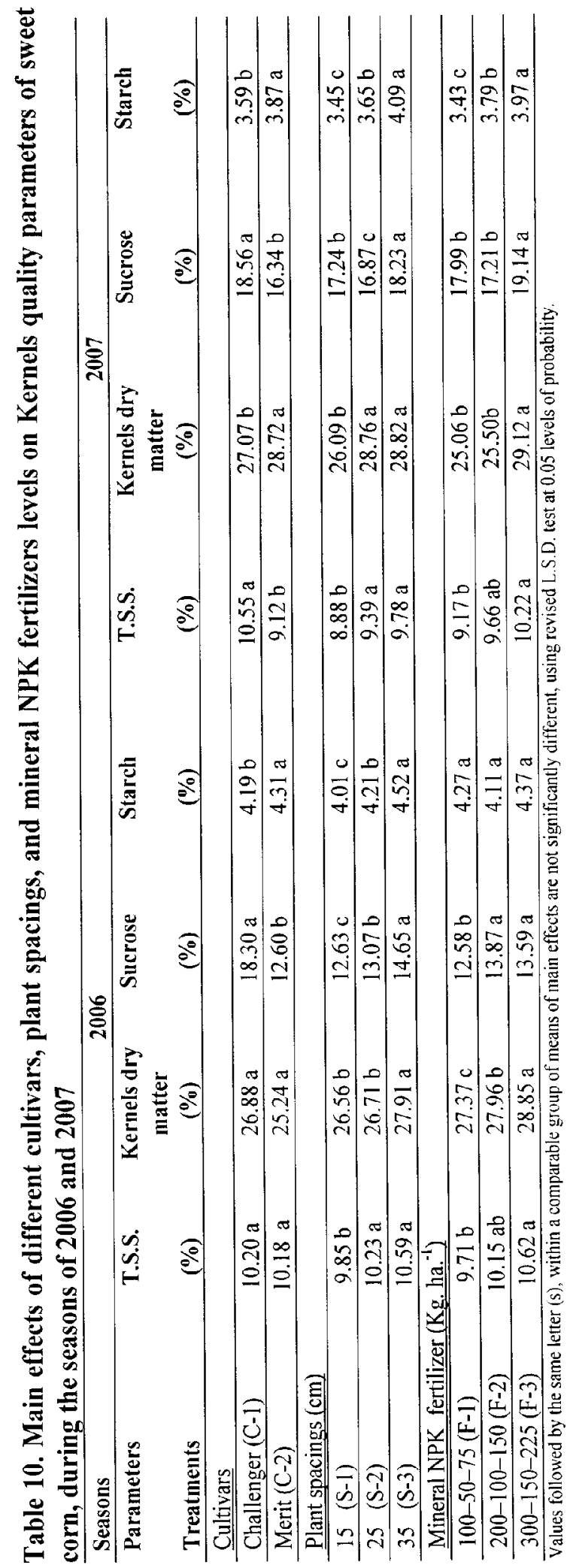




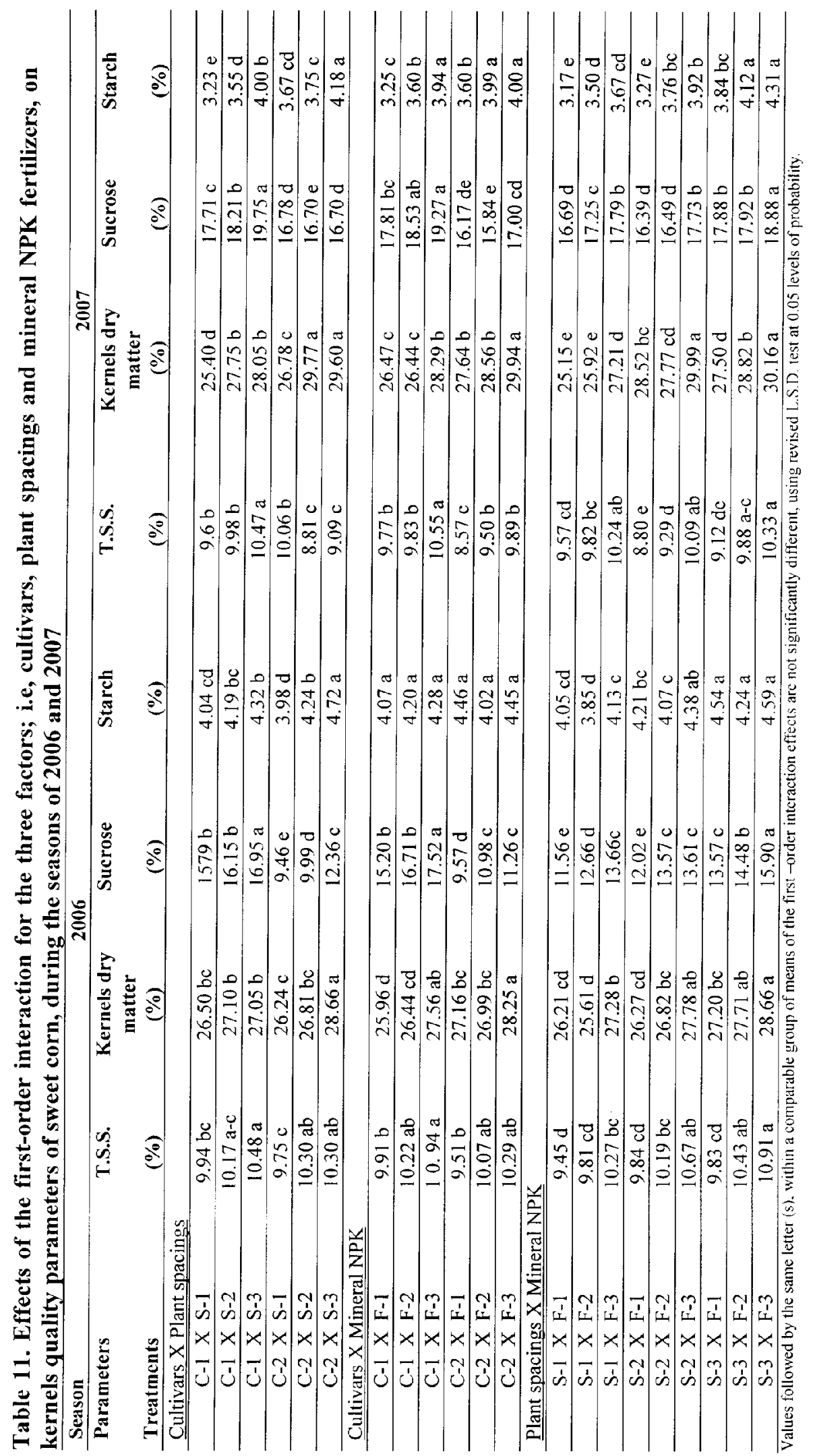




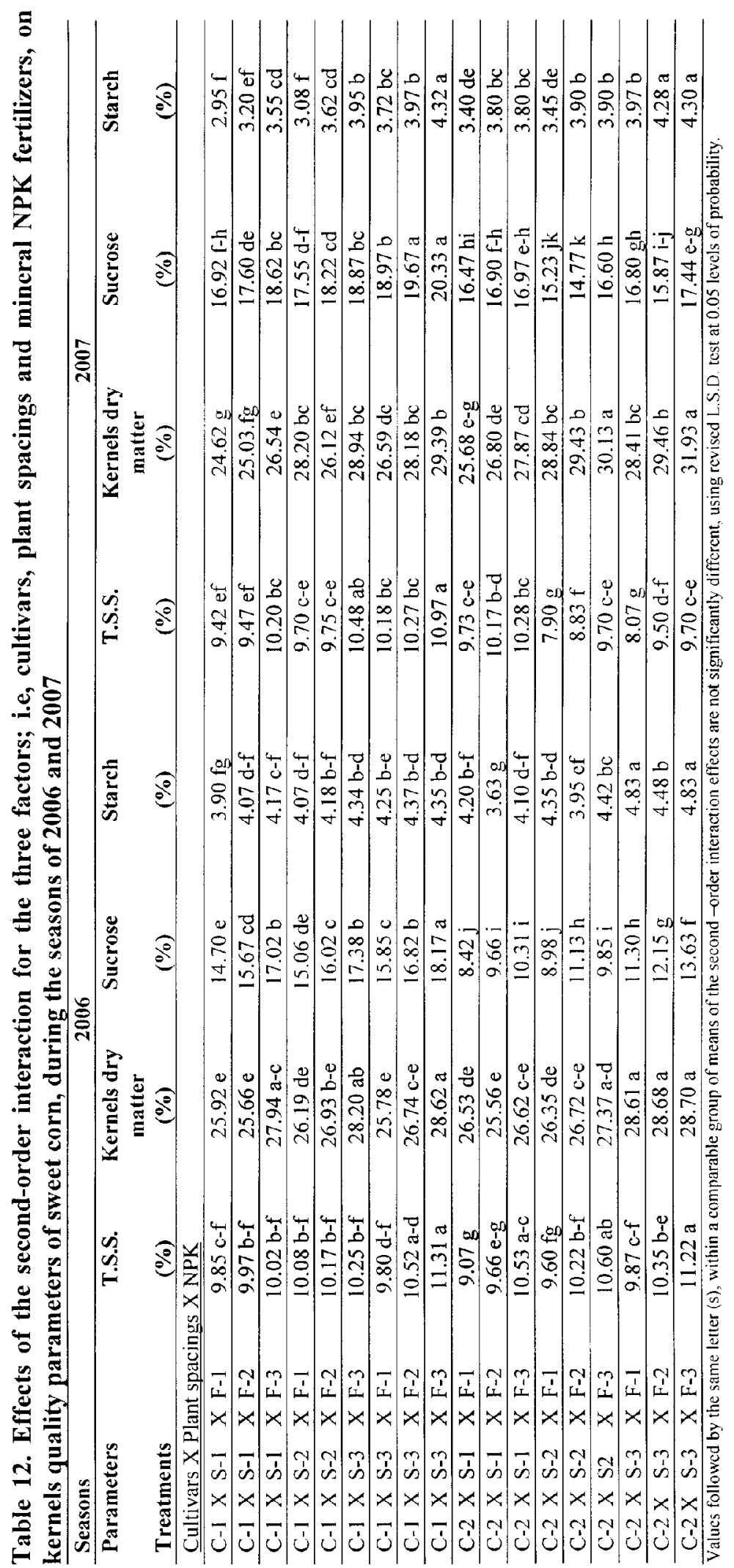


kernels dry matter and starch contents was given by the combination between the cultivar "Merit" and themineral NPK at the highest rate of $\mathrm{N}-\mathrm{P}_{2} \mathrm{O}_{5}-\mathrm{K}_{2} \mathrm{O}$, during the two seasons of 2006 and 2007.

The results presented in Table 11 showed the firstorder interaction effects between the plant spacings and mineral NPK fertilization on the kernels quality parameters of sweet corn, during the two growing seasons. The results indicated generally that the comparisons among the mean values of each kernel quality parameter appeared to be significant, but with different magnitudes, through both seasons. The best interaction that gave the highest mean values of kernel quality parameters was the combination between the third spacing between plants at $35 \mathrm{~cm}$ and the third rate of mineral NPK fertilizers (S-3 X F-3), in the two seasons.

Table 12 showed the second-order interaction effects among the three factors cultivars, plant spacings and mineral NPK fertilizers rates on kernels quality parameters, during the seasons of 2006 and 2007. The results reflected generally that the comparisons among the mean values of all studied kernels quality were found to be significant in most cases, in both growing seasons. The highest significant mean value of each total soluble solids and sucrose contents was given by the combination among the cultivar "Challenger" with the third spacing between plant at $35 \mathrm{~cm}$ and the third level of mineral NPK fertilizers at the rate of 300-150$225 \mathrm{~kg}$. N-P $\mathrm{P}_{2} \mathrm{O}_{5}-\mathrm{K}_{2} \mathrm{O} \mathrm{ha}^{-1}$., in the two seasons. On the other side, the combinations among the cultivar Merit with the plant spacing at $35 \mathrm{~cm}$ between plants and the mineral NPK fertilizers at the rate of 300-150-225 kg. $\mathrm{N}-\mathrm{P}_{2} \mathrm{O}_{5}-\mathrm{K}_{2} \mathrm{O}$ ha ${ }^{-1}$., (C-2 X S-3 X F-3) gave the highest mean values of the kernels dry matter and starch contents, during the two summer seasons. These results means that the used hybrids cultivars of sweet corn interacted will at the widest plant spacing and the highest level of NPK fertilizers, and gave the higher performances for these quality parameters.

\section{REFERENCES}

Akman, Z. 2002. Effect of tiller removing and plant density on ear yield of sweet corn (Zea mays var saccharata, Sturt). Pakistan J. Biol. Sci. 5(9): 906 - 908.

Akman, Z.1998. The effects of cultivars and sowing date on yield and gronomic characters in sweet corn. Proceeding of $2^{\text {nd }}$ Balkan Symposium on Field Crops,16-20 June 1998, Novisod, Yugoslavia. p. 343-347.

Al-Solaimani, S G.; F S. El-Nakhlawy and G. M. Basahui. (2009).Effect of irrigation water salinity, irrigation interval and sulphur fertilizer rates on forage yield, yield components and quality of blue panic grass(Panicum antictotale L)Faculty of Metrology, Environment and Arid
Land Agriculture, King Abdulaziz University, Jeddah, Saudi Arabia. 20: 113-135.

Amin, M.; A.R. Rehmatullah and M. Ramzan. 2006. Effect of planting methods, seed density and nitrogen phosphorus (NP) fertilizer levels on sweet corn (Zea mays,L.). J. Res. Sci. 17 (2): 1-2.

Bauer, P.J. and P.R. Carter. 1986. Effect of seeding date, plant density,moisture availability, and soil nitrogen fertility on maize kernel breaking susceptibility. Crop Sci. 26. 1220- 1226.

Bhargava, S.C. and S.N. Saha. 1980. Physiological analysis of the growth, development and seed yield of oil-seed sesame. Agri. Sci .Camb.95:733-736.

Boyer, C.D. and J.C. Shannon. 1983. The use of endosperm genes for sweet corn quality improvement. Pl. Breed .Rev. 1:139-161.

Bremner, J.M. 1965. Nitrogen availability indexes. In C.A. Blact et al. (ed.). Methods of Soil Analysis. Part 2.Amer.Soc.Agron.9:1324-1345., Madison, Wisconson, USA.

Chambi, J.Y. and B.R. Taylor .1986. Sesame agronomy in south-east Tanzania. 1- Plant population and sowing method. Exp. Agri. 22:243-251.

Chipman, E.W. and D.C. MacKay. 1960. The interaction of plant population and nutritional levels on the production of sweet corn. Proc. Amer.Soc.Hort.Sci.76:442-447.

Cornin, D.A.and S.Smith. 1979. A simple and rapid procedure for the analysis of reducing, total and individual sugars in potato. Potato Res .22:99-103.

CoStat Software. 2004. User's Manual Version. Cohort Tusson, Arizona. USA. htti// www. Cohort.com ., info @ cohort. com.

Doehlert, D.C.; T.M. Kuo; J.A. Juvik; E.P. Beers and S.H. Duke. 1993. Characteristics of carbohydrate metabolism in sweet corn sugary-1) endosperms. J.Amer. Soc. Hort. Sci. 118(5): 661- 666.

Eltelib, H.A.; M.A. Hamad and E.E. Ali. 2006. The effect of nitrogen and phosphorus fertilization on growth, yield and quality of forage maize (Zea mays, L.). Agron.J.5(3): 501- 518 .

Evensen, K.B. and C.D. Boyer. 1986. Carbohydrate composition and sensory quality of fresh and stored sweet corn. J. Amer. Soc. Hort. Sci. 111(5): 734-738.

Falivene, S. 1995. Improving the international competitiveness of the processing sweet corn. Industry in New South Wales, final report, HRDC Project VG227.htm.

Garwood, D.L.; F.J. McArdle; S.F. Vanderslice and J.C. Shannon. 1976. Post harvest carbohydrate transformation and processed quality of high sugar maize genotypes. J. Amer. Soc. Hort. Sci. 101: 400-404.

Hemphill, D.D. ; N . S Manour ; J . Hart ; R.Dick; J.Luna ; J , Selker; C.Miles and E. Marx . 1996. Effect of N rate and row spacing on sweet corn yield and residual soil N. A : /Vegetable research 1996, Commercial Vegetable 
Production Guides, North Willamette Research An Extension Center : htm

Jackson, M.L. 1973. Soil Chemical Analysis. New Delhi, India, Prentice-Hall, India.

Jagtap, S.S.; R.T. Alabi ,and O.A Deleye. 1997. The influence of maize density on resource use and productivity: An experimental and simulation study. J. Afri. Crop Sci. . 6(3): 1- 15.

Keating ,B.A.;B.M. Wafula and R.L. McCown .1988. Simulation of plant density effects on maize yield as influenced by water and nitrogen limitations . Proceeding of the International Congress of Plant Physiology, February 15- 20., 1988. New Delhi, India . Society for Plant Physiology and Biochemistry, New Delhi, India pp 1414.

Keating, B.A.; D.C.Gadwin and J.M.Watiki.1990.Optimizing nitrogen inputs in response to climatic rist . In: R.C. Muchow., and , J.A. Bellamy (Eds), Climatic risk in crop production models and management for the semiarid Tropics and subtropics. CAB International, Wallingford, pp.329-358.

Kleinhez, M D.2003. Sweet corn variety trials in Ohio : recent top performers and suggestion for future evaluations . Horttechnology13 ( 4 ) : 711-718.

Koteva, V. and I. Mikhov. 1995. Effect of fertilizer application on the yield of grain maize grown without irrigation in south-east Bulgaria. Rasteniev dni Nauki 32(9/10): 175- 180. (c.a . Field Crop Abst.50,3743).

Koteva. V. 1995. Effect of fertilizer application on the quality of grain maize grown without irrigation in south-east Bulgaria. Rasteniev dni Nauki. 32 (9/10): 181-183. (c.a. Field crop Abst. 50, 3744).

Lana, E.P.1956. Effects of plant population and seasons on the performance of sweet corn for canning. J. Amer. Soc. Hort. Sci.67:460-467.

Lang ,A.L.; J.W. Pendleton and G.H. Dungan.1956. Influence of population and nitrogen levels on yield and protein and oil content of nine corn hybrids . Agron.J. 48:284- 289.

Malik, C.P. and M.B. Singh. 1980. Plant enzymology and histoenzymology. A Text Manual-Kalyani Publishers, New Delhi.India.

Marschner, H. 1986. Mineral nutrition of higher plants. Academic press . court brace Jovanovich. publishers. London.San Diego, New York and Tokyo.p.673.).

Michalojc, Z; J. Nurzynski and J.M. Kossowski. 1996-a. Effect of nitrogen fertilizer application and harvesting date on yield and chemical composition of sweet corn.Annales Universitatis Mariae Curie-sklodowska. Sectio EEE, Horticultura. 4:105-111. (c.a. Field Crop Abst. 50,4644).

Michalojc,Z; J. Nurzynski and J.M. Kossowski. 1996-b. Effect of nitrogen and potassium fertilizer application on yield and chemical composition of sweet corn. Annales Universitatis Mariae curie-sklodowska. Sectio EEE, Horticultura. 4:95-103. (c.a. Field Crop Abst. 50,4645).

Miftahullah, H.A.; M.T. Jan A.Jan, and Ihsanullah. 2002. Yield potential of sweet corn as influenced by different levels of nitrogen and plant population. Asian .J. Pl. Sci. 1(6): 631-633.

Modarres, A.M.; M. Dijak: R.I. Hamelton; L.M. Dwyer; D.W. Stewart; D.E. Mather and D.L. Smith. 1999. Leafy reduced stature maize hybrid response to plant population density and planting pattern in a short growing season area. Maydica. 43 (3):227- 234

Mullins, C.A. 2000. Performance of processing sweet corn cultivars at selected spacings.Plateau Experiment station. http llbioengr.ag. utk. edu /Extension Prog/Vegetable/ yer /veg Init Report 00/S performance of processing sweet corn: htm,

Navarro, G.A.; L.M. Guerra; T.F. Corpas and R.A. Mayordomo. 1985. Maize, nitrogen rate and sowing density. Agricultura, Spain. 54 (631): 110-113. (c.a. Field Crop Abst. 39:4, 2609).

Nihayati, E. and S.Damhury. 1996. The effect of urea fertilizer application dates and splits on growth and yield of sweet corn cv, SD-2. Agrivita. 19 (2):51-56. Fakultas pertanian, universities Brawijaya, Malang, Indonesia. (c.a. Field Crop Abst.50,4643).

Oikeh, S.O.; J.G. Kling: V.O. Chude and W.J. Horst. 1997. Yield and N-use efficiency of five tropical maize genotypes under $\mathrm{N}$ levels (ed). Maize productivity gains through research and technology dissemination: roc. $5^{\text {th }}$ Eastern and Southern Agrica Regional Maize Conf. Arusha, Tanzania. 3-June 1996. Cimmyt, Addis Ababa, Ethiopia.

Park, K.Y.; Y.K. Kang; S.U. Park, and H.G. Moon. 1989. Effect of planting density and tiller removal on growth and yield of sweet corn hybrids. Korean J. Crop Sci. 34:192-197.

Patel, S.K; E.A. Hanlon, S.J. Houchmuth, and J.M. White. 1988.Nitrogen and Potassium management studies for sweet corn. Soil and Crop Sci. Flor. Proc. 47:142-146.

Peck, N.H. and G.E. MacDonald. 1973. Plant responses to concentrated super phosphate and potassium chloride fertilizer: VI. Sweet corn. New York State Agri. Expt. Sta.Geneva Search: Agr. htm.

Peck, N.H. and G.E. MacDonald. 1989. Sweet corn plant responses to $\mathrm{P}$ and $\mathrm{K}$ in the soil and to band-applied monoammonium phosphate, potassium sulfate, and magnesium sulfate. J.Amer. Soc. Hort. Sci. 114(2): 269272.

Rogers, I.S. and G.J. Lomman. 1988. Effects of plant spacing on yield, size and kernel fill sweet corn. Australian J.Exp. Agric. 28 (6):787-792.

Shelton, W.R. and Harper, H.J. 1941. A rapid method for the determination of total phosphorus in soil and plant material. Iowa State College, J. of Sci. 15: 403-413.

Steel, R.G.D. and J.H. Torrie, 1984. Principles and procedures of statistics. $2^{\text {nd }}$ ed., McGraw Hill Book Co. Inc. Singapore, pp. 172-177.

Sukanya, T.S.; H.V. Nanjappa, and B.K. Ramach. 1998. Growth parameters and yield of baby corn as influenced 
by varieties and spacing. Mysore J. Agric. Sci.32(4): 264268.

Tetio-kagho, F.and F.P. Gardner. 1988. Responses of maize to plant population density. II. Reproductive development, yield and yield adjustments. Agron.J. 80:935-940.

Tosheva, E. 1995. Optimization of fertilizer application for maize at different nutrient contents of leached cinnamon forest soils.Rasteniev "dni Nauki" 32 (9110): 132-135. N. Pushkarov Institute of soil Science, Agrochemistry and Ecology, Sofia, Bulgaria. (c.a. Field Crop Abst $.50,3742)$
Wong, A.D.; J.M. Swiader and J.A. Juvik. 1995. Nitrogen and sulfur fertilization influences aromatic flavor components in shrunken 2 sweet corn kernels. J. Amer. Soc. Hort Sci. 120(5):771-777.

Yodpetch, C. and O.K. Bautista. 1984. Sweet corn (Zea mays, L.) as potential young cob corn II. Fertilization and population density. Philippine Agriculturist. 67(2): 121134. (c.a. Field Crop Abst. 39 :4,2653).

Zhong, S.L. 1998. Sweet corn varietal trial. AVRDC - ARC Research Report. Fill://c: \ Documents and setting । Administrator $\backslash$ Desktop $\backslash$ sweet corn varietal trail. htm. 


\title{
الملخص العربي
}

\section{تأثير الأصناف ومسافات الزراعة والتسميد المعلدن المركب على النمو الخضرى والخصول ومكوناته و التر كيب الكيماوى والجودة للذرة السكرية}

\author{
زهير محمود مرداد
}

الأصناف على القطع الرئيسية، ومعاملات مسافات الزراعة علــى القطع تحت الرئيسية أما معاملات التسميد فوزعت على القطع تحت - تحت الرئيسية، ولقد أوضحت الدراسة النتائج التالية.

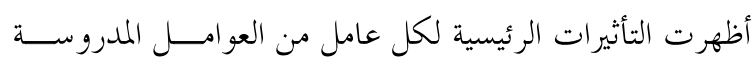
منفصلا و كذلك التداخلات لكل من النوع الأول و النــوع ع الثــانى وذلك على كل من صفات النمو الخضرى والمحصول والجحودة للذرة

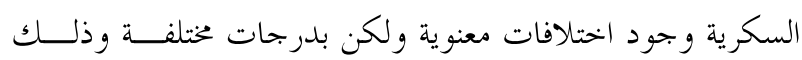
خلال موسمى الزراعة. أظهرت النتائج بصفة عامة أن صنفى الذرة السكرية يختلفان في سلو كهما العام، حيث عكست قيم معظم الصفات للنمو الخضرى والصفات المحصولية وكذلك الجودة للحبوب ومحتوى الأوراق مــن

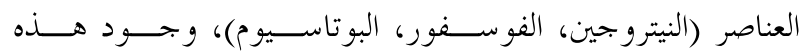

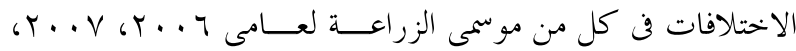

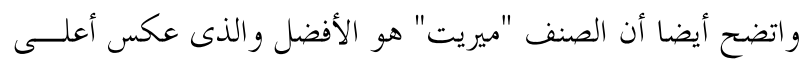

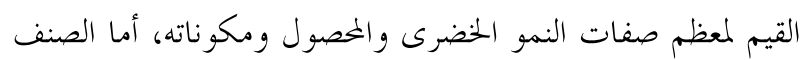
"تشالنجر" فأعطى أعلى القيم لصفات الجودة حيث اتضح أن زيادة مسافة الزراعة أو زيادة معدل التسميد المعدلن المركب ارتبط بزيادة صفات الجمودة للذرة السكرية خحلال موسمى الزراعة. عكست النتائج أيضا بصفة عامة أن التداخلات سواء كانـــت من النوع الأول أو النوع الثان كان لها تأثيرات على كل الصفات

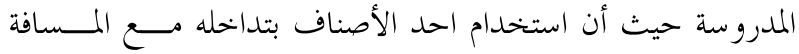

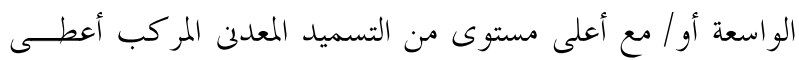
أعلى القيم للصفات المدروسة جميعا خلال موسمى الزراعة.

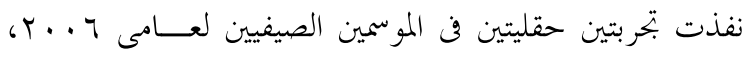

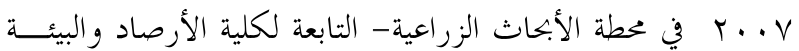
وزراعة المناطق الجحافة بجامعة الملك عبدا لعزيــز، .منطقـــهـ هــــى الشام.المملكة العربية السعودية، وذلك هُدف دراسة تأثير كل مــن صنفين من الذرة السكرية (تشالنجر - ميريت) كمحصول خـــض

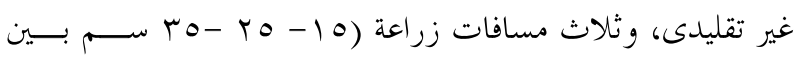

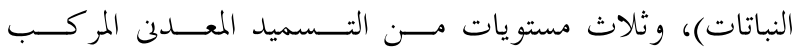

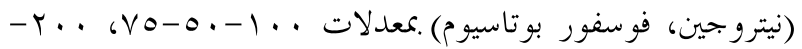

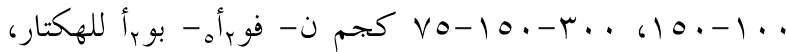
كذلك جميع التداخحلات الممكنة بينهم، وذلك على صفات النمـــو الخضرى (ارتفاع النبات- قطر الساق- عدد الأوراق للنبــات النسبة المئوية للمادة الجافة للأوراق) وصفات المصصول ومكوناتــه (عدد الكيزان/ نبات- وزن الكوز بالغلاف- وزن الكوز بــــون

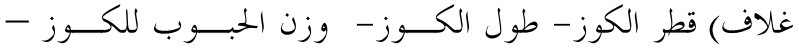
المخصول الكلى للكيزان/هكتار- الخصول الكلى للحبوب/هكتار) وكذلك صفات الجودة للحبوب. (النسبة المئوية للمـــادة الجحافــة للحبوب- محتوى الحبوب من كل من السكروز، السكريات الكلية، السكريات المختزلة، المــــواد الــصلبة الذائبـــة الكليـــة، النـــــا، الكربوهيدرات) بالإضافة إلى محتوى الأوراق من عناصر النيتروجين،

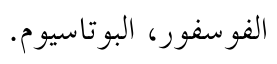

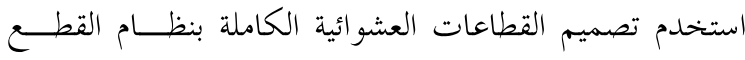
المنشقة لمرتين وذلك بثلاث مكررات، حيث وزعت معاملات 